\title{
Effect of Sodium Citrate on the Blood Disappearance of ${ }^{67} \mathrm{Ga}^{\dagger}$
}

\author{
Hiroyuki KoHNo, Yasuhito OHKUBO and Akiko KuBODERA* \\ Department of Radiopharmacy, Tohoku College of Pharmacy \\ 4-1, Komatsushima 4-chome, Sendai-shi 983, Japan \\ *Department of Radiopharmacy, School of Pharmaceutical Sciences, \\ Science University of Tokyo \\ 12, Ichigaya Funagawara-cho, Shinjuku-ku, Tokyo 162, Japan \\ Received May 11, 1987
}

\begin{abstract}
The effect of sodium citrate on the blood disappearance of ${ }^{67} \mathrm{Ga}$ was examined in rats. The half life value of the alpha phase and the initial AUC value (0-60 min) were dose-dependently decreased by sodium citrate. The binding of ${ }^{67} \mathrm{Ga}$ to serum proteins was also dose-dependently inhibited by sodium citrate.
\end{abstract}

Key Words: gallium-67, sodium citrate, pharmacokinetic analysis, protein binding, rats

\section{Introduction}

Radionuclide ${ }^{67} \mathrm{Ga}$ which is widely used for detection of tumor $^{1,2)}$ and inflammation ${ }^{3)}$, has been demonstrated to bind easily to serum proteins, chiefly transferrin ${ }^{4)-i}$. The binding capacity of ${ }^{67} \mathrm{Ga}$ to serum proteins has been reported to be decreased by sodium citrate ${ }^{(6), 8), 9)}$. In addition it has also been reported that commercially available ${ }^{67} \mathrm{Ga}$-citrate containing different dose of sodium citrate shows different physicochemical behavior each other ${ }^{10)}$. However, there are no detail reports concerning the effect of sodium citrate on the blood disappearance rate of ${ }^{87} \mathrm{Ga}$. Then we examined the effect of sodium citrate on the pharmacokinetics of ${ }^{67} \mathrm{Ga}$ in this report.

$\dagger{ }^{67} \mathrm{Ga}$ の血中消失に及结すクエン酸ナトリウムの影 響。河野弘之, 大久保恭仁, *久保寺昭子 : 東北楽 科大学放射薬品学教室, 983 仙台市小松島 4-4-1,

* 東京理科大学楽学部放射薬品学教室, 162 東京 都新宿区市谷船河原町 12 。

\section{Experimental}

2.1 Pharmacokinetic study

${ }^{67} \mathrm{GaCl}_{3}$ was diluted with physiological saline to $925 \mathrm{kBq}(25 \mu \mathrm{Ci}) / \mathrm{ml}$ and a volume of 0.2 $\mathrm{ml}(185 \mathrm{kBq})$ containing various doses of sodium citrate was administered to the femoral vein, then a $20 \mu 1$ volume of the blood was repeatedly taken via the catheter inserted into the external jugular vein ${ }^{11}$. The radioactivity of the blood was counted in a well-type NaIscintillation counter and its value was represented as a ratio in order to correct the body weight of each rat by the equation: (blood radioactivity (cpm)/blood weight $(\mathrm{g})) /($ injected radioactivity $(\mathrm{cpm}) /$ body weight $(\mathrm{g}))$. The pharmacokinetic parameters of ${ }^{67} \mathrm{Ga}$ were calculated based on a 2-compartment model using a pharmacokinetic analysis program (MULTI) for a microcomputer ${ }^{12}$.

\subsection{Protein binding study}

The binding capacity of ${ }^{67} \mathrm{Ga}$ to serum proteins was determined by ultrafiltration using Centriflo membrane cones (type CF50A) with 


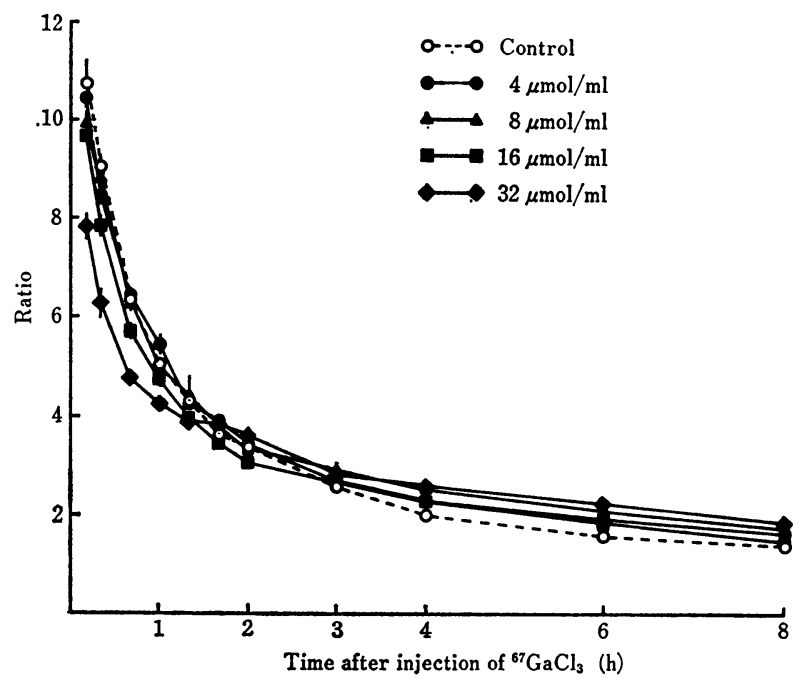

Fig. 1 Effect of sodium citrate on the blood disappearance of ${ }^{67} \mathrm{Ga}$.

Each value represents the mean and SEM of 4 rats.

Table 1 Pharmakokinetic parameters of ${ }^{67} \mathrm{Ga}$ following intravenous administration with various doses of sodium citrate

\begin{tabular}{ccccc}
\hline $\begin{array}{c}\text { Dose } \\
(\mu \mathrm{mol} / \mathrm{ml})\end{array}$ & $\alpha$-phase & $\beta$-phase & $0-60 \mathrm{~min}$ & $60-120 \mathrm{~min}$ \\
\hline 0 & $30.0 \pm 2.0$ & $408.2 \pm 68.0$ & $481.7 \pm 16.7$ & $243.9 \pm 6.2$ \\
4 & $31.4 \pm 0.5$ & $490.3 \pm 53.8$ & $473.1 \pm 6.9$ & $254.1 \pm 5.8$ \\
8 & $26.5 \pm 2.5$ & $475.6 \pm 62.9$ & $467.6 \pm 18.9$ & $247.3 \pm 13.5$ \\
16 & $23.5 \pm 0.8$ & $373.5 \pm 50.2$ & $433.2 \pm 7.5$ & $226.4 \pm 4.0$ \\
32 & $18.5 \pm 3.0$ & $405.6 \pm 13.9$ & $357.7 \pm 13.3$ & $232.9 \pm 11.1$ \\
\hline
\end{tabular}

Each value represents the mean and SEM of 4 rats.

a more than $95 \%$ retention for molecules above $50000 \mathrm{MW}$. Gallium-67 (18.5 kBq/50 $\mu 1)$ was incubated in the rat serum $(950 \mu 1)$ with various doses of sodium citrate for $20 \mathrm{~min}$ at room temperature. An aliquot $(800 \mu 1)$ of each sample was then transfered to the membrane cone and centrifuged at $1000 \mathrm{~g}$ for 10 $\mathrm{min}$ at room temperature. Another aliquot $(50 \mu 1)$ was transfered to a counting tube and served as a total radioactivity. After centrifugation the radioactivity of the filtrate was counted in a well-type NaI-scintillation counter. Data were represented as \% filtration calculated by the following equation: (radioactivity filtrated/ total radioactivity applied) $\times 100$.

\section{Results and Discussion}

The effect of sodium citrate on the blood disappearance curve and the pharmacokinetic parameters of ${ }^{67} \mathrm{Ga}$ are given in Fig. 1 and Table 1, respectively. Sodium citrate accelerated the disappearance rate of ${ }^{67} \mathrm{Ga}$ only in the early phase after the injection. The half life value of the alpha phase was dose-dependently shortened, but the one of the beta phase was not shortened by sodium citrate. The area under the time-ratio curve of ${ }^{67} \mathrm{Ga}$ during 60 min after the injection of ${ }^{67} \mathrm{Ga}$ was also diminished dose-dependently, but one between 60 and $120 \mathrm{~min}$ was not influenced by sodium citrate. This transient action of sodium citrate on the blood disappearance of ${ }^{67} \mathrm{Ga}$ seems to be due to its rapid degradation, about $60 \%$ of citrate has been reported to be metabolized to $\mathrm{CO}_{2}$ by $60 \mathrm{~min}$ after intravenous injection ${ }^{13)}$. It is unable to relate the result of pharmaco- 


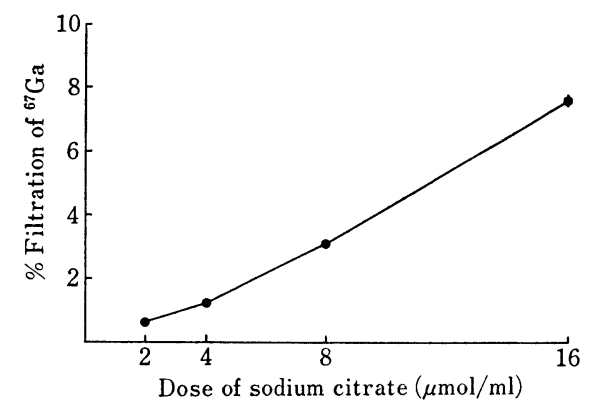

Fig. 2 Effect of sodium citrate on the ${ }^{67} \mathrm{Ga}$ binding to serum proteins.

Each value represents the mean and SEM of 4 determinations.

kinetic study with that of in vitro study directly, since the concentration of sodium citrate in the blood seems to be considerably low compared to that in the solution used in the binding study. Nevertheless, this facilitating action of sodium citrate on the blond disappearance of ${ }^{6 \pi} \mathrm{Ga}$ is probably due to the action on the protein binding of ${ }^{67} \mathrm{Ga}$, because the protein binding rate of ${ }^{67} \mathrm{Ga}$ also decreased almost proportionally to the dose of sodium citrate (Fig. 2).

\section{References}

1) Hoffer, P.B.: J. Nucl. Med., 21, 394-398 (1980)

2) Hayes, R.L.: "Recent Advances in $\mathrm{Nu}$ - clear Medicine", Vol. 6, pp. 177-197, Grune \& Stratton, Inc., Orlando (1983)

3) Hoffer, P.B.: Int. J. Nucl. Med. Biol., 8, 243-247 (1981)

4) Hara, T.: ibid., 1, 152-154 (1974)

5) Clausen, J., Edeling, C.J. and Fogh, J.: Cancer Res., 34, 1931-1937 (1974)

6) Tsan, M.F., Scheffel, U., Tzen, K.Y. and Camargo, E.E.: Int. J. Nucl. Med. Biol., 7, 270-273 (1980)

7) Vallabhajosula, S.R., Harwig, J.F., Siemsen, J.K. and Wolf, W.: J. Nucl. Med., 21, 650-656 (1980)

8) Hartman, R.E. and Hayes, R.L.: J. Pharmacol. Exp. Ther., 168, 193-198 (1969)

9) Hnatowich, D.J., Kulprathipanja, S. and Beh, R.: Int. J. Appl. Radiat. Isot., 28, 925-931 (1977)

10) Waxman, A.D., Kawada, T., Wolf, W. and Siemsen, J.K.: Radiology, 117, 647648 (1975)

11) Kohno, H., Suzuki, T., Ohkubo, Y. and Kubodera, A.: Radioisotopes, 33, 269272 (1984)

12) Yamaoka, K., Tanigawara, Y., Nakagawa, T. and Uno, T.: J. Pharm. Dyn., 4, 879885 (1981)

13) Simpson, D.P.: Am. J. Physiol., 205, 1049-1052 (1963) 